\title{
Fostering eGovernment as State Social Responsibility (SSR): Case Study of an Australian City Council
}

\author{
*Singara Rao Karna, **Divya Kirti Gupta \\ *Center for Electronic Government \& Open Democracy (CEGOD), Bangalore-560034, India,e-mail: s.raokarna@gmail.com \\ **Indus Business Academy, Greater Noida, India e-mail:divyakirti@rediffmail.com
}

\begin{abstract}
Democracies around the world face citize apathy. This is a concern now more than ever faced by countries around the globe. eGovernment is undoubtedly a platform to deliberate and enable citizens regain confidence and faith in democratic processes. Citizens now seek Verifiable, Open, Transparent, Empathetic, Responsive and Sensitive Electronic Democracy and Government (VOTERS EDG, Karna, 2012). Similar to the corporate world, there are voices stressing on governments for the need to understand the stakeholders, their involvement, relationships and responsibilities of a state in eGovernance. Citizens everywhere now demand Verifiable, Open, Transparent, Empathetic, Responsive and Sensitive Electronically Democratic Government as a State Social Responsibity (SSR). Peoples movements and outbursts against authorities with the help of Word of Mouse (Karna, 2012) have established that transparent and open governance is the need of the hour. This paper presents findings of the study conducted in an Australian City Council for preparing the city council for 'City e-readiness' to initiate e-Government activities. We propose the idea of 'Centrality of Citizens' in context of eGovernment. We further build upon the original concept of deeming eGovernment as 'State Social Responsibility' (SSR) (Karna, 2010), by governments at all levels.
\end{abstract}

Keywords: State Social Responsibility, eGovernment, Citizen-Stakeholder, Citizen-Customer, Stakeholder Networking, Holistic Globalization, ISO26000, Corporate Social Responsibility, VOTERS EDG, Word of Mouse

Acknowledgement: The Authors thankfully acknowledge the motivation, support and kind perusal of the document by Dr. Ushio Sumita, Professor, Graduate School of Systems and Information Engineering, Tsukuba University, Ibaraki, Japan; Dr. Subhash Sharma, Director, Indus Business Academy, Bangalore, India and Dr. Karunesh Saxena, Professor, Faculty of Management Studies, Mohanlal Sukhadia University, Udaipur, Rajasthan, India.

T he concept of e-government is a reality now. It is here to stay and will grow further and will mature with each passing day. Long time has passed since the year 2005 when UN published its UN Global eGovernment Readiness Report (2005). According to the 2005 report, governments were at different levels in the delivery of eGovernment services. It reported some developed countries migrating from eGovernment to iGovernment 'Internet Connected Government', while some other States were in transactional phase of eGovernment and still others were at the initial phase of eGovernment, with static website delivering very few services online. Sweden emerged as leader in eReadiness followed by US (as per the report) and only $2 \%$ of the States lacked online presence. Discussions and debates have continued since then on the happenings across world and on hurdles and challenges being faced or envisaged in reaching the ideal state of e-Government. Certainly, the journey so far, has not been simple and easy because, there is no universal fit. Each State has to arrive at its own appropriate fit taking into consideration the socio-economic-cultural-political-diversity mix and infrastructural \& technological capabilities.

UN eGovernment Survey (2008) looked at the movement from eGovernment to connected governance from the perspective of how governments manage and how they should manage their back office processes to establish themselves as connected governments with citizens and other 
stakeholders. The latest UN eGovernment Survey (2010) spelt out that, "The value of egovernment will increasingly be defined by its contribution to development for all. Citizen-centricity, inclusiveness, connected government, universal access and use of new technologies such as mobile devices are the benchmarks against which electronic and other innovative forms of public service delivery will be assessed". 2010 report also compares scores of top 20 countries on eparticipation in 2010 and 2008. Kazakhstan, Slovenia, Germany, Bahrain and Malaysia have shown tremendous improvement in their e-participation score, whereas, the score of US, Denmark and France have taken a dip. It may be noted here that Australia which ranked 5th in 2008 rose by three ranks and became 2nd in 2010.

UN eGovernment Survey (2012) focuses on people and gives special emphasis to role of vulnerable population in bridging digital gap. It states, "Vulnerable populations are particularly important in this comprehensive perspective because the standard Information and Communication Technology (ICT) penetration, ICT take-up and enabling environmental conditions may not always be applicable to their specific attributes, needs and wants. Thus, a specific focus on vulnerable populations is useful and necessary for overcoming the barriers that governments of the world face in their drive to ensure the digital inclusion of all citizens, thereby contributing to efforts towards ensuring sustainable development for all".

The motivations for eGovernment are many. Speed, wider reach, increase in transparency and accountability of the office bearers, cost efficiency and effective, convenient way of delivering services to the citizens are few of many reasons. No doubt all this is hugely being facilitated by advancements in Information and Communication Technology (ICT), and availability of that technology for eGovernment work. Moreover, citizen-apathy towards the governments is a challenge that democracies are facing across the world. It is viewed that adopting eGovernment will increase civic-involvement leading to social inclusion and active citizen-participation, alleviating current citizen apathy.

UN eGovernment Survey (2012) also provides very relevant data on vast gap between eGovernment usage and EGovenment availability, both in developed and developing countries and suggests active role that can be played by social media for increasing the usage.

We aim to further develop the original concept of deeming eGovernment as State Social Responsibility (SSR) (Karna, 2010); propose the idea of 'Centrality of Citizen' as key to success of eGovernment implemenaton in a democratic set-up; discuss the relevance of Verifiable, Open, Transparent, Empathetic, Responsive and Sensitive Electronic Democracy and Government (VOTERS EDG) concept (Karna,2012.); and Review the performance of an Australian City council in above areas.

United Nations E-Government Global E-Readiness report (2005) defined eGovernment as, 'The use of information and communication Technologies (ICT) and its application by the government for the provision of information and basic public services to the people'. This definition clearly emphasizes the extensive use of ICT in making information and services available to the people at all levels of a State. The American Society for Public Administration (2008) defined eGovernment as, 'The governance practice that includes the use of all information and communication technologies, from fax machines to wireless palm pilots, to facilitate the daily administration of government'. Hence, like eCommerce, the popular interpretation of eGovernment is the one that defines it exclusively as an Internet driven activity. But, ASPA goes a step further and makes it clear that - 'eGovernment improves citizen access to government information, services and expertise to ensure citizen participation in, and satisfaction with the government processes. It is a permanent commitment by government to improving the relationship between the private citizen and the public sector through enhanced, cost-effective and efficient delivery of services information and knowledge. It is the practical realization of the best that government has to offer to the citizens'. It is clear that role of ICT is that of a facilitator, but still it is an important element, as the availability of ICT and its cost efficiency will have defining effect on the entire pursuit of eGovernment. 
Similar elements are considered by Seifert\&Chung (2009), but they bring-in spirit-of-democracy into the ambit of eGovernment, when they define eGovernment as a combination of two key elements i) Improvements in provisions of governmental service quality and cost reductions in the administration through ICTs ii) Inclusion of more social dimension of participatory eDemocracy, such as on-line voting and fostering greater social inclusion through eCommunity involvement. The definition by Groznik (2008) delves further, and addresses various key aspects of democracy, which should be upheld under all conditions by everyone (more so by Democracies). These aspects are: Enhanced expression of democratic values, Greater inclusiveness and say of people in State's governance, and citizen empowerment. They define eGovernment as 'The intensive or generalized use of information technologies in government for the provision of public services, the improvement of managerial effectiveness and promotion of democratic values and mechanisms'. Mcloughlin\&Comford (2006) looked at e-Government as a programme of transformation, which implies changes in structures, processes, working practices and corporate cultures, thereby having a bearing on everybody involved with the local government. These include elected members, staff and, of course, citizens and local business in their various dealings with the local authorities and requiring extensive partnership to coordinate and join service providers for effective co-ordination with national departments and agencies.

Further, the role of meaning ware in political participation and concept of citizenship in digital age with their implications for Political (and Social) Science are also being discussed (Brady and Reuben, 2010).

Thus, review of existing literature makes it very clear that, eGovernance and eGovernment not only have technical implications, but they also have far reaching social, cultural, political and economic implications for countries as well as organizations. This makes it imperative, that countries critically assess their eReadiness before embarking on the journey of eGovernment. Once embarked, 'Roll back' may not be a possibility. After over a decade of active consideration, adoption and adaption, many countries have made their foray, the early movers being USA, Sweden, Canada, Australia and New Zealand. Service delivery through electronic means (eService), (Internet being the most used tool), has taken a center-stage at all levels of governments, more so at local authority. All over the world, city (municipal) councils are becoming usually the first points of citizen contact, reach and interaction.

We are of the opinion that governments will have to think beyond ICT deployment. They will have to examine prevailing management systems, work processes, hierarchy/structure, culture, stakeholders and then develop a consensual strategy for active citizenship, participation and partnership with stakeholders (employees, citizens, NPOs, businesses etc.) while encouraging networking among stakeholders, at all levels. Partnering with local community is essential to encourage active citizen-participation and civic engagement.

In the following section, we further build upon the original concept of State Social Responsibility (Karna, 2010) and propose the idea of 'Centrality of Citizens' in eGovernment. eGovernment fostered with SSR zeal and following the V.O.T.E.R.S EDG framework will garner greater support from civic society. Implications of these perspectives for the entire process of eDemocracy and eGovernment are discussed.

\section{Conceptual Framework of State Social Responsibility (SSR)}

As per ISO 26000, International Standard on Social Responsibility of organizations takes into its ambit many important aspects: Responsibility of an organization for the impacts of its decisions and activities on society and the environment, Transparent and ethical behavior, Sustainable development, Respecting stakeholder interests, Compliance with applicable law, Respect human rights and integrate Social Responsibility throughout the organization. As is evident from these aspects, a government ministry or institution involved in the process of eGovernment has to incorporate all the above, in order to act in a socially responsible manner. 
This complexity demands that respective governments and democracies should look the domain of eGovernment as State Social Responsibility. This idea of fostering eGovernment as State Social Responsibility (SSR) was first proposed and coined by Karna (2010). Skill and will to share the power of decision making with citizen-customers and other stakeholders, such as NGOs and NPOs, through eGovernment forms foundation of the concept of SSR. Skill should include technological capabilities along with managerial competencies.

We opine that eGovernment can not only be technology intensive, but will also demand greater transaction, interaction, sensitization of governments and will to share power. It is suggested that social scientists, civil societies and citizens be directly involved, not only in understanding the City e-readiness levels, but also in generating awareness to understand the problems and challenges, and estimating the resources required and balancing them with the resources available. UN Global eGovernment Readiness Report, (2005) provides guidelines on accessibility and social inclusion by way of providing access to disadvantaged groups, supporting ICTs use for socio-economic development and promoting social cohesion and consensus on socially inclusive approaches. The report also highlights the great potential of ICTs for eGovernment in reducing gender accessdivide. The report states that ICTs can help women enhance economic and social empowerment and greater political participation.

Moreover, as cited earlier in the paper, eGovernment has to uphold the basic values of democracy, which means that entire endeavour has to be with a mission of SSR. Initiation and implementation of eGovernment project at local and federal government levels per se does not usher-in SSR, but by constant education, motivation and encouraging networking amongst citizens and all other stakeholders in the community. This strategy promotes the usage of online government services and e-participation in democratic processes actively (Karna, 2010a).

Looking at the complexity involved in initiating eGovernment projects and issues raised by researchers and practitioners, it can be very well understood that if progress towards eGovernment is made with zeal of State Social Responsibility (SSR), then there is tremendous potential for eGovernment to succeed and advance its maturity into Politically Participatory eDemocracy. Potentially, SSR provides the very quintessential foundation for interplay of varied socio-political, technological, economic and ethical concerns and aspirations of people in a country, and countries across the globe. The fervor of SSR is important in eGovernment because citizens are emerging as most important entity in the entire conceptualization and implementation of eGovernment.

To rejuvenate the waning democratic spirit (among citizenry) and to mitigate the associated citizen apathy, VOTERS EDG framework was conceptualized by Karna (2012).

\subsection{V.O.T.E.R.S EDG}

The acronym V.O.T.E.R.S reflects - Verifiable, Open, Transparent, Empathetic, Responsive and Sensitive Electronically Democratic Government. "The VOTERS framework perfectly aligns with the application of the Public Value concept to deliver citizen - customer value, (a term which is apt given that citizens play active role as customers and primary stakeholders in eGovernment now), i.e. to citizen - customers" (Karna, 2012). VOTERS framework also provides Civic Society a platform for collective reasoning (deliberation) on a large scale to find solutions as civic ends through civic means in active participatory mode of democracy; being active partner/stakeholder, decision maker and service receiver of electronically governing Governments leading to electronic Democracy (Karna, 2010a, Schuller, 2011).

The VOTERS EDG framework actually aligns with the application of the Public Value concept to deliver citizen - customer value, (a term which is apt given the citizens play active role as customers in eGovernment now), i.e. to citizen - customers. VOTERS framework also provides Civic Society a platform for collective reasoning (deliberation) on a large scale to find solutions as civic ends through civic means in active participatory mode of democracy; being active partner/stakeholder, decision maker and service receiver of electronically governing governments leading to electronic Democracy (Karna, 2010a, Schuller in Karna 2012). At the outset, the 
essence of VOTERS framework could be fully attained by eGovernment through Democratization of technology and business processes which imperatively is eDemocracy - the need of the hour (Karna, 2010a; Bhattacharya, 2011). Elliman et al (in Karna, 2012) are of the view that growth and development in the relationship between government bodies and the citizens would define the future trajectory of this domain. Das et al (2008) in their work tested the relationship between eGovernment and trust and suggested that e-government can potentially impact the development of open source software, because open source software lies in public domain, and in order for the society to adopt it, there needs to be a higher level of trust. Williamson (in Karna, 2012) emphasizes empowerment of citizens in eGovernment, wherein they have the ability to influence and affect public policy and diversity of opinions \& where knowledge is valued. Hacker et al (2009), acknowledged the existence of 'Digital Divides' and how the inequalities of participation in network society governmental systems can affect the extent of individuals' empowerment and disempowerment within those systems. According to them there is likelihood of Digital Divide gaps contributing to structural inequalities in political participation. They further opine, 'These inequalities work against democracy and political empowerment for some people, while at the same time producing expanded opportunities of political participation for others. This raises concerns as to who benefits the most from electronic government in emerging network societies'.

\subsection{Centrality of Citizens in eGovernment}

UN $(2005,2008,2010)$ provide practical framework and guidance for eParticipation, as follows:

E-Information: Government websites provide information on policies and programs, budgets, laws and regulations; along with other briefs on key public interest. Tools for broadcasting of information are available for timely access and use of public information, including web forums, email lists, newsgroups, and chat rooms.

E-Consultation: The government website explains ways and means of e-consultation and tools, while offering choice of public policy topics online for discussion with real time and archived access to audio and video of public meetings. The government encourages citizens to participate in discussions.

E-Decision-making: The government informs that, it will take citizen input into decision- making, while undertaking to provide actual feedback on the outcome of specific issues.

Lim et al (2007) provided a stakeholder dimension to eGovernment against the backdrop of strategic orientation of control and collaboration management philosophy. Their study looked at eGovernment from three critical aspects of Stakeholder Management: i) Identification of stakeholders ii) Recognition of dissimilar interests within stakeholders iii)Ways and means of an organization catering to and furthering interests of these groups. Wong et al (2007) also argued similarly that there is an urgent responsibility for government to involve stakeholders in driving eGovernance through eGovernment and ICT forward at local, state, national and international levels, for societal as well as economic benefits. Brady \& Rubens (2010) considered ethical dimension of information exchange as important in this impending paradigm shift.

Seeing the emerging presence of eGovernment, experts and scholars see awareness generation and involvement of people in the process of eGovernment as crucial. It is clear that the citizen holds a key position. 'Four global forces' suggested in context of 'Holistic Globalization Model' by Sharma (2007) are very much relevant in understanding the 'Centrality of Citizens' to the concept and purpose of eGovernment. Sharma opines that Force of Market, Force of State, Force of People and Force of Self are always in dynamic interaction with each other, and when these forces are in harmony, there is synergy (Fig.1). 


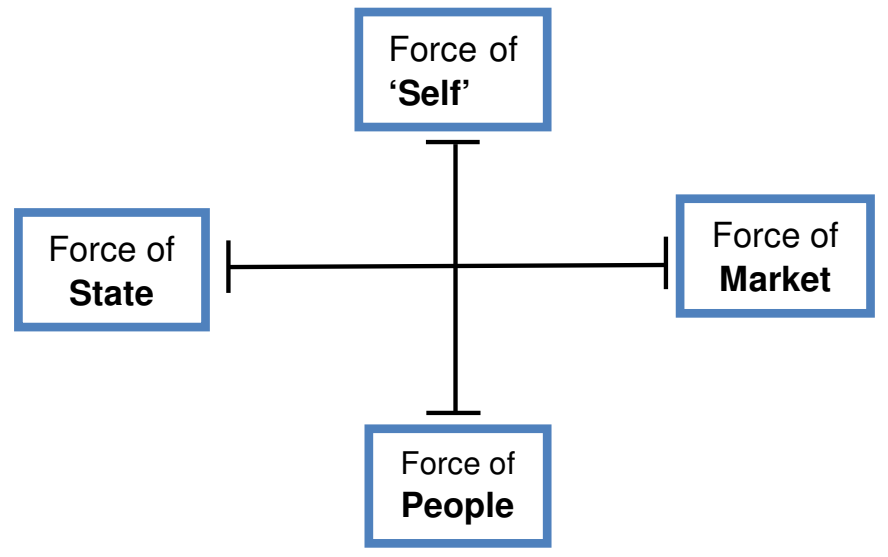

Fig. 1 - Model of Holistic Globalization

(Source: Sharma (2010), 'Beyond Pyramid and Pyramid Thinking: Pyramid vs Coconut model of Thinking')

In light of above discussion, we propose that 'Citizen' be considered as center of these forces (Fig. 2). This placement of citizen at the center provides direction to the planners and implementers to work for complete success of eGovernment in any country or economy.

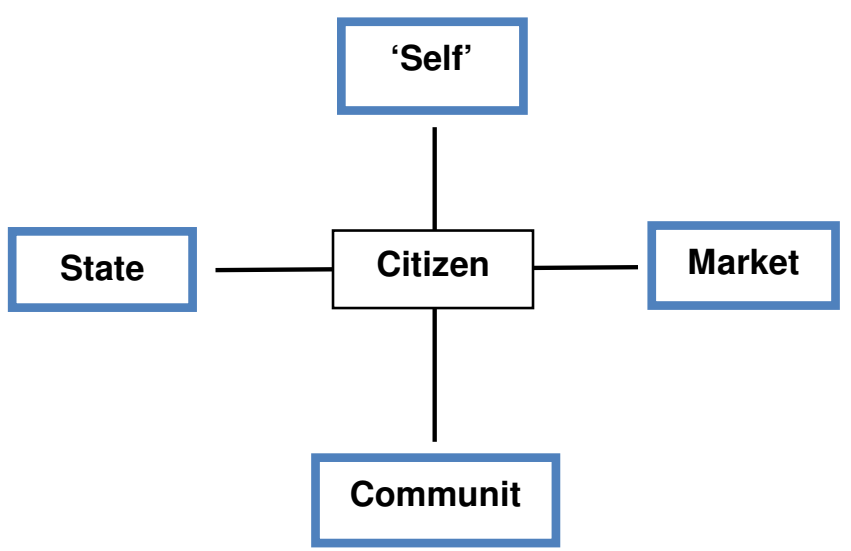

Fig. 2 - 'Citizen' Placed at the Centre of the 'Model of Holistic Globalization'

On doing so, the citizen is a primary driver and will have 4 expressions - 'Customer' in the context of Market, will be a 'Rightful Owner' in context of the State, 'Primary Stakeholder' in context of Community and 'Enlightened Individual' in context of Higher Self, with all elements of four forces dynamically interacting with each other; and conscious efforts and interventions being made to strike a balance among all the forces and elements.

The successful experiment on participatory budgeting for improving budget transparency and improvement in execution reported by Mbera (2012) illustrates the centrality of citizens as 'rightful owner' and 'primary stakeholder' of the process of e-governance. UN survey report of 2010 also lays particular attention to assessment of e-participation in light of citizen centric governance. Since e-participation has not been defined very well, the report states, 'This is particularly relevant at the local level where individuals are most likely to come into contact with public agencies. To what degree are governments providing supporting information, actively consulting with citizens through online channels, and involving them in decision-making as a matter of course? Each of these aspects of citizen-centric governance must be defined in concrete, measurable terms, and 
corresponding data collected, in order to monitor the relationship between online services and citizen empowerment'. It goes a step further and complements e-government development index with an e-participation index. Further, the e-participation tools being designed also have inbuilt challenges. Awareness about them, technology intensiveness, availability and allocation of resources, appropriateness of tools, their acceptability and institutionalization etc., are some of such challenges, further complicated by the tools being used today have to be futuristic too. Openness to change and belief in e-participation being integral to e-Government may be taken as major psychological challenges.

The increase in the number of users increases the sphere of e-Government, which means that citizens get defined as 'customers' and 'consumers' of an increasing e-Government market in the world. Hence, work on increase in user-base will help countries achieve 'economies of scale'.

The discussion on inclusion of vulnerable population, economic conditions of nations, promotion of participation of women in e-Governments, discourse on sustainable development within eGovernment (UN Survey reports of 2012 and 2012) indicate that there is lot of thinking which is happening and discussions are being encouraged to bring in completeness to the process of governance. This shows that proponents of EGovernment are allowing the integration of responsible and responsive side of human entity to the development of e-Government. This shall impetus if SSR attitude is adopted by nations while developing eGovernment in their places.

Having elaborated on deeming eGovernment as SSR (Karna, 2012) and 'Centrality of Citizen', as a key aspect in eGovernment, the paper further focuses on these aspects in relation to Australian City Council for putting the city council on City e-readiness level; to initiate subsequent e-Government phases for moving towards a fully transactional and relational eDemocracy stage in Australia.

\subsection{The Political Power of Word Of Mouse through Social Media and ICTs}

Success of ICTs and Social Media in causing political change beginning in Philippines, spreading to Egypt, Tunisia etc. encouraged citizens in other countries to pick up the conversation. It helped create discussion across the regions as a shared grievance (Taylor, 2012). The traditional word of mouth be it positive or negative has now assumed as: Word of Mouse (Karna, 2012) through the development of World Wide Web, ICTs and Social Media. With the advent of mobile phones and smart mobile phones the Word of Mouse assumed a dramatic importance given the speed with which a word of mouth could be passed on through a mouse or even a simple touch far and wide across the globe.

The first ever forcible exit of a politically elected head of a state - President Estrada of Philippines happened though a word of mouse and SMS means. More than a decade ago, on January 17, 2001, during the impeachment trial of Philippine President Joseph Estrada, loyalists in the Philippine Congress voted to set aside key evidence against him. Within two hours after the decision's announcement, thousands of Filipinos, angry that their corrupt president might be let off the hook, gathered on Epifanio de los Santos Avenue (EDSA), an iconic crossroads in Manila. The protest was arranged, in part, by forwarded text messages reading, "Go 2 EDSA. Wear blk." The crowd soon swelled, and in the ensuing few days, over a million people arrived, choking traffic in downtown Manila. The civic society's ability to coordinate such a massive and rapid response -close to seven million text messages were sent that week -- so alarmed the country's legislators that they reversed their decision favoring Estrada and allowed the evidence to be presented. Estrada's was gone by January 2001. The event marked the first time that social networking media and ICTs had helped force out a national leader. Estrada himself blamed "the textmessaging generation" for his downfall. After the rise of the Internet in the early 1990s, the world's networked population has grown from the low millions to the low billions. Over the same period, Social Networking Media have become a fact of life for civil society worldwide, involving many actors - regular citizens, activists, non-governmental organizations, telecommunications firms, software providers, governments (Shirky, in Karna 2012). This phenomenon has been clearly 
observed/repeated as shared grievance in social up-rise of Indian Civil Society for "2011 India's Anti-Corruption Movement", with the only difference that Indian Government managed to stall mobile networks in certain parts of Bombay, during a hunger strike event of the Gandhian (Karna, 2012).

\section{2. eGovernment and Australian Perspective}

Australia has 721 city councils. During year 2010, Australia implemented its e- Government plans as Data Centre Strategy (Australian Government Data Center Strategy (2010), through Ministry of Finance and Deregulation, with a view to providing Data Storage facility for the ICT industry. All agencies under the Finance Ministry and Accountability Act (FMA) support most government programs delivering services to citizens and businesses. This Strategy caters to future data center requirements with initiatives and actions to achieve $\$ 1$ billion savings in costs which are used for building infrastructure in ICT industry for the next 10-15 years thus taking Australia to top position in the world ranking for e-readiness and e-Governance. Instituting National Office of Information Economy (NOIE) was the most strategic initiative for taking e-Government forward in Australia providing leadership on the whole gamut of government information management strategies from overseeing policy, to defining specifications and offering guidelines for fresh initiatives. Economist's annual global E-Readiness Rankings (2009), ranked Australia at fourth place among the top ten, after the US, Hong Kong and the Netherlands.

According to the UN e-Government Survey 2012, Australia is at 12th position with development index of 0.8390 .

Table 1: World eGovernment Development Leaders as per UN E-Government Survey 2012

\begin{tabular}{|l|l|l|}
\hline Rank & Country E-government & Development Index \\
\hline $\mathbf{1}$ & Republic of Korea & 0.9283 \\
\hline $\mathbf{2}$ & Netherlands & 0.9125 \\
\hline $\mathbf{3}$ & United Kingdom & 0.8960 \\
\hline $\mathbf{4}$ & Denmark & 0.8889 \\
\hline $\mathbf{5}$ & United States & 0.8687 \\
\hline $\mathbf{6}$ & France & 0.8635 \\
\hline $\mathbf{7}$ & Sweden & 0.8599 \\
\hline $\mathbf{8}$ & Norway & 0.8593 \\
\hline $\mathbf{9}$ & Finland & 0.8505 \\
\hline $\mathbf{1 0}$ & Singapore & 0.8474 \\
\hline $\mathbf{1 1}$ & Canada & 0.8430 \\
\hline $\mathbf{1 2}$ & Australia & 0.8390 \\
\hline $\mathbf{1 3}$ & New Zealand & 0.8381 \\
\hline $\mathbf{1 4}$ & Liechtenstein & 0.8264 \\
\hline $\mathbf{1 5}$ & Switzerland & 0.8134 \\
\hline $\mathbf{1 6}$ & Israel & 0.8100 \\
\hline $\mathbf{1 7}$ & Germany & 0.8079 \\
\hline $\mathbf{1 8}$ & Japan & 0.8019 \\
\hline $\mathbf{1 9}$ & Luxembourg & 0.8014 \\
\hline $\mathbf{2 0}$ & Estonia & 0.7987 \\
\hline
\end{tabular}

Similar to all other countries, low e-participation from citizens is an immediate challenge for Australia probably due to lack of direct, online consultation by governments at various levels coupled with a weak presence of elected representatives and political parties online (Bruns and Wilson, 2009). This situation resulted in calls for steps on war footing basis with an increasing trend in net savvy citizens networking among themselves to portray government lacunae with location independence and demand for transparency. Lack of Trust on Internet is a definite major factor for low e-participation as has been observed by other researchers (Colesa and Dobrica, 2009; Das and Burbridge, 2008). 


\subsection{Australian National Broadband Network (NBN) Initiative: What can the NBN do for citizens and other stakeholders?}

The NBN has the potential to transform many aspects of our lives including home internet and telephone services in areas such as education, business, entertainment and access to online health services.

A) Phone: Once built, the NBN will also deliver telephone service to citizens. b) Teleworking: It is the federal government's goal that by 2020, at least 12 per cent of Australian employees will report having a teleworking arrangement with their employers. The NBN can make working from home easier with the ability to access a quality broadband experience and enabling to use services provided over the NBN to access videoconferencing, virtual offices and giving the ability to upload large files from the comfort of employee's own home. c) Education: Services delivered over the NBN have the potential to change the way people learn and teach. The NBN may help more Australians to easily access a greater education wherever they live. For kids in a small school in the outback, a single mum studying from home, or a disabled student, that's a brighter future. d) Online Health: The opportunities for advancements in medical technology are one of the most exciting aspects of the NBN. The expansion of access to care through interactive internet consultations, supporting telemedicine and addressing health shortages through internet based care are some of the ways that services are expected to be offered over the NBN to address the medical gap between urban and regional Australians. In the future, regional patients could have access to online services that provide the ability to consult with their specialist and local doctor simultaneously via video conference. This will provide greater comfort as well as possible time savings and reduced cost. e) Entertainment: The NBN could be used by service providers to offer a broad range of entertainment choices including internet connected television streaming video-ondemand services, super fast online gaming and high quality video calling from a lounge room. Of course, people will also need the right software, equipment and in-premises connection to access these services. f) Business Solutions: Once built, the NBN has the potential to change the way businesses conducted by helping companies overcome the barriers of distance. It is expect that access to high speed broadband will give businesses the opportunity to increase productivity, save time and money and the ability to compete on a global scale (NBN Co, 2012).

The services provided over the NBN may open up opportunities for businesses to hold virtual meetings or liaise with suppliers across Australia online - potentially saving time and costs associated with travelling.

\section{Methodology}

A post-hoc analysis of action research and exploratory case study conducted in the City of Plenty (disguised name) is followed to gauge the extent of city's compliance with the concept of SSR. Given the nature of such a research aim, case study and histories have become a choice of investigation (Yin, 2003). The initial study as a part of in-house process innovation team of business analysts (through action research and exploratory case study) was undertaken to revamp business processes and technology so as to socially include citizen-customers and other stakeholders for encouraging collective social responsibility and leverage collective wisdom. Perusal of council's archives threw light on pre-eGovernment era of this council. Open-ended questionnaire interviews were conducted with employees concerned, with a prior appointed time and place. Brainstorming sessions, Edward De Bono (1999) workshops preceded interviewing of concerned senior, middle level and front-end staff, top down. The research primarily focused on citizenry, civic community and all other stake holders for their active civic e-participation, social inclusion and social cohesion. The community-inclusive attitude brought this council to what it is today as an innovative one winning many accolades from state and federal governments. The Australian case is interesting because Australia stood at fourth place on Global E-Readiness Rankings(2009) and Australia was one of the early movers into eGovernment. This case enables us to analyze the extent to which, the city eGovernment is marching forward on aspects of stake 
holder inclusion and active citizen e-participation. The motivation for this research is Paskaleva's(2008) suggestion of examining organization for its hierarchy, processes and culture before, duringand after initiationof eGovernment projects.

\section{City of Plenty: Description}

'Working together with the community to improve opportunities for the people of Plenty' is the slogan adopted by this council. In the Mayor's words -"Ours is the third most culturally diverse municipality in Victoria, we understand how vital that commitment is. We demonstrate it through our 28 programs and plans supporting diversity." In year 2009, the City became one of two municipalities to trial a major three year Victoria Health program called the Localities Embracing and Accepting Diversity (LEAD) Project (2011).

The City is among the fastest growing municipalities in Victoria, with population forecast to double over the next 20 years. There are around 40,000 dwellings with a population of 146000 in the City. The municipality faces the complex and distinctive challenges of balancing the dynamics of urban and rural areas, rapid growth, social disadvantage and high demand for services. The City has one of the most culturally diverse populations, with over $57.3 \%$ of residents from Non-English Speaking Backgrounds and has the fourth highest population of indigenous people in metropolitan Melbourne. The City is characterized by pockets of high socio-economic disadvantage, ranking as the fifth most disadvantaged in Australia. It also ranks the third lowest on Melbourne's Index of education and occupation and the sixth lowest on the Index of Urban disadvantage(City of Plenty, 1999).

This city has higher than average number of people aged below 25 years age necessitating the city to generate jobs locally. One third of residents are born overseas with migrants from over 50 countries. 48 percent of residents are from Non English Speaking Backgrounds (NESB). English, Italian, Macedonian, Greek, Arabic and Vietnamese are major spoken languages. Broadly, the council's community can be categorized as: 1) Rate Paying Residents 2) Non-Rate paying Residents.

Rate Paying Residents needed to be reached from view point of Annual Rate Calibration, payment arrangement, rate justification queries, installments, credit card payment mode, rate assessment depending on family situation etc. With regard to Non-Rate paying Residents all other facilities and considerations given to residents and citizens within city applied.

A deeper segmentation of entire council residents is: i) Families with Children below 18 years ii) Empty Nests (Couple with grown up children away from home) iii) Pensioners and Senior Citizens (over 65 years age) iv) Non-English Speaking Background residents vi) Latest Immigrants vii) Refugees and Asylum Seekers viii)People With Special Needs (Disabled) ix) Businesses (RealEstate Developers; Retail Malls, Restaurants etc) x)Non-Profit Organizations, Non-Governmental Organizations and others with interest in the City xi) Employees coming To work (from other city council areas) xii) Visitors and Tourists.

\section{Case Discussion and Analysis}

The city of Plenty was an example of a typical traditional municipality before embarking on eGovernment project during 1999. The council was headed by a techno-savvy Chief Executive, supported by a proactive senior management and a pro-community 'elected membership of council'. However, the organizational structure, culture, middle and lower employees were to some extent incompatible for an eGovernment project to start with. This could be attributed mostly to employees' perception of another impending 'Golden Handshake' subsequent to the one the council introduced in 1999. The very first phase of organizational restructuring in 1999 resulted in automation of business processes by way of introducing a centralized Database 'Authority' that was outsourced to a consultant firm. Thus, process-automation preceded process-innovation, which is a logical practice on 'Process Innovation Continuum'. Subsequently, from year 2000, 
the council wisely decided to design and align their business processes in a phased manner, through their own 'In-house Process Innovation' team, organized from within council's human resource expertise (Karna, 2010). This arrangement was aimed at keeping the knowledge and core competence of employees specialized in revising existing processes to devise new citizen-centric processes. The first author, as a part of this team ('Business Analyst Project Officer') witnessed employee resistance initially, which was mitigated by building a personal rapport. In order to redesign processes, the in-house team in cooperation with the marketing group of the council, analysed and arrived at the tasks of identification and segmentation of stakeholders so as to devise processes suitable to individual citizen groups in community for receiving services electronically through all forms of possible channels of delivery i.e. anytime, anywhere, anyway.

\subsection{Identification of Crucial Stakeholders}

Stake is considered as having interest or share. Crucial stakeholder identification has been considered as inevitable aspect of corporate governance (Caroll, 1989). Other researchers elaborated further to identify strategic shareholders, on whose presence firms survival capability hinges and to channelize corporate resources towards these specific niches of stakeholdersFreeman, 1984). Ultimately the purpose of eGovernment can be served only through eliciting citizen and other stakeholder opinions, active civic-engagement and encouraging dialogue with citizens through a Virtual Socialization Process (Lim et al, 2007). This helps city (through the in-house process teams) to understand reasons for citizen-apathy for devising eGovernment processes and programmes to entice citizen back into public governance and instill trust, morale and confidence. In this process, citizen-stakeholders and non-citizen stakeholders also provide support continuously in co-designing, conceptualizing, implementing, maintaining and strategizing public services as posited by Lim et al (2007). This approach clearly puts apart the democratically elected and represented government bodies to make difference for themselves from commercial applications of stakeholder theory

The proactive approach of public bodies, such as this municipal council, to reach out to all concerned categories of stakeholders, starting with primary stakeholders (citizens), paved way for moving out of rigid bureaucratic and red-tape oriented process to a citizen-customer centric process of social inclusion. Based on the characteristics of various segments of stakeholders, the city devised various far reaching eGovernment strategies and also encouraged networking of stakeholders among themselves for leveraging their active participation in democratic processes electronically (Lim et al, 2007) which is a reality now as can be observed on council's portal site. With the centrality of citizen concept, the citizen hee is a customer in the context of Market, a Rightful Owner in context of state, Primary Stakeholder in context of Community and Enlightened Individual in context of higher self. Higher self

\subsection{Measuring up to Stakeholder Interests and Networking amongst Stakeholders}

Looking from citizen-centric and civic-engagement point of view, the council has provided something for everyone as elaborated on their website portal. The eGovernment initiation strategy of 1999, as depicted in table 2 speaks of establishing interactive and transactive electronic presence by providing electronic channels for improving quality, effectiveness and efficiency of all major services. Universally, rate payments and building plan approvals assume top most priority for rate paying citizen-customers. Our analysis of the council shows that now rates are payable online through a credit card with non-English language, audio/video and Bailey reading assistance coupled with manual assistance over phone or in person at council premises as the case may be in majority spoken languages - Macedonian, Arabic, Italian, Vietnamese, Greek, Turkish along with English. Based on what has been achieved so far since year 2000, the current vision statement 2025 (Council Annual Report, 2011)envisions the council's accountability of social responsibilities to various segments of citizen-customers and other stakeholders on their web portal. 
Table 2. Objectives and Goals of Electronic Service Delivery (source: City Portal, 2011)

\begin{tabular}{|l|l|}
\hline Objectives & Goals \\
\hline $\begin{array}{l}\text { Establish a city's } \\
\text { interactive and transactive } \\
\text { electronic presence for } \\
\text { improving quality, } \\
\text { effectiveness and } \\
\text { efficiency of services }\end{array}$ & $\begin{array}{l}\text { ProvideESD channels for all major council services. Provide } \\
\text { electronic channels of communication between community } \\
\text { and council. Purchase all goods and services for council } \\
\text { electronically. Assess technology areas of video } \\
\text { conferencing, virtual reality, interactive voice over telephone, } \\
\text { speech recognition and synthesis, public kiosks, handwriting } \\
\text { recognition, digital imaging and smart cards for application } \\
\text { within council }\end{array}$ \\
\hline $\begin{array}{l}\text { Continue to develop } \\
\text { efficient and effective } \\
\text { electronic Internal systems } \\
\text { for communication \& } \\
\text { reporting within council }\end{array}$ & $\begin{array}{l}\text { All relevant staff to be trained on use of authority database. } \\
\text { Provide standardized internal processes by electronic }\end{array}$ \\
\hline $\begin{array}{l}\text { Provide widespread } \\
\text { access of council Internet } \\
\text { to community \& } \\
\text { businesses }\end{array}$ & Facilitate increased Internet connection by community \\
\hline
\end{tabular}

\section{3. eGovernment Implementation and Stakeholder Inclusion in the City of Plenty}

SSR aspects in City of Plenty are identified and discussed in this section based on original eGovernment strategy document of 1999; against the back drop of what is accomplished so far over a decade of eGovernment initiation as follows:

i) Civic Engagement (citizen-customers as primary stakeholders along with others with a stake);

ii) Funding/ Investment Involved;

iii) Transparency;

iv) Accountability;

v) Training (internal and external stakeholders);

vi) Infrastructure Development for eGovernment;

vii) Knowledge \& Information Dissemination.

\subsubsection{Civic Engagement}

Civic engagement through City Community Projects (CCF Projects) has been a tremendous success in considering citizens as primary stakeholders and community in general. The partners in the City of Plenty Community Futures Project are committed to community participation and strengths-based approach to achieve project outcomes and increase the capacity and resilience of the community. In response to this growing demand, the City joined together in a substantial partnership with over 40 human services agencies, community-based organizations and state government departments to deliver the City Community Futures (CCF) Project. The vision of the CCF partnership is to create a connected and inclusive 
community that shapes its own future achievable through developing innovative service models. Partnering with community, city of Plenty pursued for improved services and facilities for families, children and young people. Since its inception in 2006, CCF has steadily evolved into a strong partnership of multidisciplinary agencies working towards a common goal. The CCF Partnership has earned its reputation as planning and advocacy body of this city Community. Currently, six community partnership groups are supporting the development of six projects. The Senior Citizens Multicultural Program offers a range of events and activities that provide older people with relevant information on opportunities for social interactions.

\subsubsection{Funding}

Funding is predominantly from federal eGovernment Projects, State Level Projects and partially from within council. Total contribution of existing manpower towards City eGovernment project from time to time is shouldered by city. The City does not receive adequate levels of funding for many basic services. Increased State and Federal Government investment in social infrastructure and program delivery is needed to achieve a basic level of service provision.

\subsubsection{Transparency}

Transparency in the area of Customer Service pertaining to Building Planning Permit, the council has after a decade of eGovernment project initiation now provided online progress tracking facility for applicants. Undue delay, if any, caused can now be pinned to the concerned staff member for immediate redressal. Council also introduced online payment provision of rates, parking penalties, pet registration fees, debtor payment and event facility fees. Based on the observations of 'walkthroughs' with citizen-customers and developer- customers (Real Estate), during process redesign, the most delayed process was perceived to be Planning Permit application and approval which is now addressed to with transparency. However, applying electronically and receiving planning permit electronically is the vision of initial eGovernment project that is to be accomplished by the council in near future.

\subsubsection{Accountability}

Accountability concerns the answerability of the government to the public pertaining to its performance. The information and interactivity provided through various news bulletins and links to e-magazines shows the city is more responsive to individual citizen demands and needs. In 2004, a Strategic Plan for Human Service Delivery in the City was developed that was instrumental in identifying the gaps in human service delivery within municipality, as well as identifying unmet community needs and funding disparities between municipality and other municipalities. This Plan was also successful in securing funding for the establishment of the "Community Futures Partnership" - bringing together over 40 key non-government and government organizations that have a stake in the delivery of services to the city residents. The revised strategy would provide a coordinated 'whole of municipality' approach to the enhancement of community services and facilities in city through cooperative planning, infrastructure, program and policy development and funding.

\subsubsection{People Training}

People Training (employees and the city's community) could not be given much importance during the initial stages of eGovernment. The reason could be attributed to lean and mean manpower status due to an organizational restructuring exercise as already discussed. The golden handshake policy resulted in sending away of existing staff members from various departments and in getting casual staff members on hourly basis. The paradox faced by city was as to who to train when and where to train. Permanent staff were limited and pre- occupied with their basic responsibilities, in some cases even sharing responsibilities of other departments (for example 
planning officers partly working at Customer Service Desk). Casual staff couldn't be easily deployed for training given their status of temporary tenures. However, over a period the council has put in place regular training for employees in tune with the eGovernment processes as a result of which the city won many awards for their outstanding engagement of community and for innovative ways inviting community participation and social inclusion. For the citizen stakeholders in the city, the council initiated free training 'on the use of broadband for over 1500 residents and 200 businesses in the municipality' to start with.

\subsubsection{Infrastructure development for eGovernment}

Infrastructure development for eGovernment: The City of Plenty succeeded through their leadership role representing the needs of its community, outer metropolitan areas and the local government sector for installing faster broadband services. Working with industry, Victorian State Government (through 'Vic Urban') and with end users (to ensure their maximum use of the services) the City of Plenty accomplished advanced broadband services for their community. The Victorian State Government had initially installed a fiber to the solution for up to 8000 residents, delivering five play services (phone, internet, FTA TV videos on demand and pay TV) over a 100 megabit link. This council symbolizes Australia's rapid advancing year by year on their innovative strength of enhanced connectivity - in fixed and broad band access(2010). Australian Federal National Broadband Network - the first national, high speed broadband network for all Australians, regardless of where they live is currently the pinnacle of high speed internet. Australian Federal Government's initiative of National Broadband Network for high speed internet facility through Interim Satellite Service is available in several areas around Australia. City of Plenty is included in this interim arrangement while work is progressing to provide full broadband facility in this council among selected areas in the first phase. National Broadband Network released a three year rollout plan with construction planned to commence in over 1500 communities and 3.5 million premises throughout Australia through to 30th June 2015 (NBN 2012).

\subsubsection{Knowledge and Information Dissemination}

Knowledge and Information dissemination: Increased information is delivered on a regular basis and as a testimony the council publishes city scene e-magazine quarterly; a latest news bulletin, links to various city event information and weather warnings. However, an audio video presentation of council meetings is an expected information to be delivered online similar to councils in Europe, who are close to reach participatory democracy level (from Web Presence to Interaction to Transaction to Transformation to final stage of e-democracy of political participation on the evolutionary ' 5 Stage Maturity Model' (Siaou and Long, 2005). All these modes of information dissemination in real time empowers citizens to develop more proximity to council to access information for witnessing the transparency and judging city's performance (Wong, 2004). In late 2008, the Australian Federal Government's Department of Broadband Communication, and the Digital Economy (DBCDE) introduced their 'Digital Economy Consultation Blog. City of Plenty is one of 40 per cent of Australian local councils with online citizen feedback provision through their websites. All other municipalities are under pressure from citizen-customers and other stake holders to provide eGovernment service delivery on par with eCommerce in other walks of life(O'Toole,2007).

\section{Analysis of Case Study Observations \& Four Conceptual Frameworks.}

i) State Social Responsibility (SSR)

ii) Corporate Social Responsibility(CSR) in eGovernment

iii) Centrality of Citizenry (balancing four dimensions of citizen)

iv) V.O.T.E.R.S Electronically Democratic Government (VOTERS EDG) 


\subsection{State Social Responsibility (SSR)}

The term is coined by Karna (2010) with a view to draw a parallel to Corporate Social Responsibility (CSR) at a time when the elected presidents of the United States of America (beginning with Bill Clinton) submit that they are the CEOs and are bound to deliver value to the taxpayer's money. A socially responsible state or government should recognize that the electorates are:

- Primary Stakeholders with an interest for seeing that governments are run as per aspirations of citizenry based on what is enshrined in a constitution

- Decision makers in legislating new laws

- Citizen-Customers for receiving government services

The UN report on eGvoernment survey (2010) indicates that benefits of eGovernment are defined measured by its contribution to development for all accentuating:

- Citizen-Centricity

- Inclusiveness

- Connected Government

- Universal Access

- Use of new technologies

As can be seen from the previous discussion, the city of plenty recognizes citizenry as primary stakeholders and involves them as decision makers following a segmented stakeholder approach. Citizenry is also considered as customers for receiving government services with a universal access and inclusiveness accentuating Citizen-Centricity. The use of multi lingual audio and video facility on the web portal is a testimony for using new technologies in delivering local government services to citizenry. Thus the eGovernment as a State Social Responsibility (SSR) is apparent in city of plenty eGovernment implementation.

\subsection{Corporate Social Responsibility (CSR) in eGovernment}

ISO 26000, international guidance standard emphasizes on Good governance, Responsibility for decisions on society and environment, Transparent and ethical behavior, Respecting stakeholder interests, Respect for human rights

\subsection{Centrality of Citizens}

The City of Plenty respects the citizens as primary stakeholders and businesses and NGOs as other stakeholders and also respecting their rights by providing networking amongst these stakeholders within the city by way of gatherings, newsletters and magazines according to the demographic needs.

The idea of 'Centrality of Citizens' suggests that the citizen becomes the center of eGovernment conceptualization and functioning where the four forces of citizens, representing four dimensions get addressed and balanced. Those dimensions are it being a 'Customer' in the context of Market, 'Rightful Owner' in context of the State, 'Primary Stakeholder' in context of Community and 'Enlightened Individual' in context of Higher Self.

The case study observations show that the citizen is given the rightful place as a customer in the context of Market; a rightful owner in the context of the state with a various choices provided by the city in owning responsibility for the economy, wellbeing of the City of Plenty. As a primary stakeholder, the city provided plenty of choices for setting the agenda for the economic and social welfare of people of all cultures, age and gender. The opportunities provided in form of these measures enable an individual i.e. citizen to self-actualize and self-realize enlightenment. In a globalized world, the citizen is the basic starting entity to work with and make him/her part of 
globalization process so that there is no human face lost in the all-pervading globalization. Thus, starting from grass-root local government level a citizen could be empowered, enlightened and rightfully placed at the center of globalized phenomenon forces. This way a holistic globalization (Sharma, 2007) can be ushered in.

\subsection{V.O.T.E.R.S Electronically Democratic Government (VOTERS EDG)}

Karna (2012) proposed the concept of V.O.T.E.R.S EDG. This framework actually aligns with the application of the Public Value concept to deliver citizen - customer value, (a term which is apt given that citizens play active role as a voter (exercising franchise), a stakeholder and a citizencustomer receiving government services. The acronym V.O.T.E.R.S is formulated based on the following meaningful functions for each alphabet:

- Verifiable: Authenticate; Certifiable; Possible to verify; a verifiable account of the incident

- Open: Free of prejudice; receptive to new ideas and arguments

- Transparent: free from deceit or fraud; free from pretense or deceit; frank: easily detected or seen through; obvious; readily understood; characterized by visibility or accessibility of information especially concerning business practices

- Empathetic: Commiserative; compassionate; sympathetic; humane; understanding and warm hearted

- Responsive: Responsive to the needs of customers; receivers of products and services

- Sensitive: Involving discretionary authority over important policy matters

VOTERS EDG framework through Verifiable provides insight to the public on how decisions are made and how elected officials or public servants are held accountable for their actions, while expecting the governments to be empathetic to citizens' unknown needs; (a highway road that might be needed 10 years down the line, but citizens wouldn't be entirely clear about the feasibility and other external factors); Open in Open Government, Open Data, Open Information and Open Innovation stand for the changing relationship between citizens and government authorities. Open government is to be seen in the context of citizen rights, the right to actively participate in the process of agenda setting and decision making (Schuller, 2011). Transparency pertains to show that business processes are free from deceit or fraud. The Indian government recently planned to pay the wages of daily wage workers though an automatic transfer with a message left on workers mobile phone. Empathy to gauge and understand the citizens problems and constraints from their point of view given the arying demographics among citizenry as individuals in a society. Responsiveness as in taking preemptive actions based on citizens' personal experiences with their long association with the suburbs they live in (Bushfire preventions in areas that are prone, but governments may lack one hundred percent appreciation of the problem, unless citizens are made to network among themselves and co-design the necessary services in consultation with the local government's employees). Sensitivity as in honoring various regional, linguistic, religious sentiments while law making.

Verifiability as in case of Social Audits in India (State of Andhra Pradesh), where public works are verified by way of reading out the works done, expenditure incurred, workers employed, wages paid etc., in front of a villagers' meeting and all genuine expenditures ratified while bogus payments ghost workers (namesake) are detected and the guilty punished. Thus, public could become a direct and prominent influence in government legislature to a larger extent (Bhattacharya, in Karna 2012). Verifiability in form of "social audits" is turning welfare recipients into whistle blowers Verifiability offers an unheralded cure for the corruption that plagues India's national jobs and subsidies programs (Karna, 2012).

Based on the case discussion, the City of Plenty falls under the category of VOTERS EDG framework whereby it provides Civic Society a platform for collective reasoning (deliberation) on a large scale to find solutions as civic ends through civic means in active participatory mode of democracy; being active partner/stakeholder, decision maker and service receiver of electronically 
governing Governments leading to electronic Democracy (Karna, 2010a, Schuller, 2011). At the outset, the essence of VOTERS framework could be fully attained by eGovernment through Democratization of technology and business processes which imperatively is eDemocracy - the need of the hour (Karna, 2010a; Bhattacharya, 2011).

\section{Conclusion}

As illustrated beginning the journey as early as 1999 , this city council's momentum to evolve into a full-fledged politically-participatory eDemocracy, has been continuous. The council is partnering with primary stake holders i.e. citizens along with businesses and other civic groups within the community in a segmented manner to reach out according to their needs of multi-cultural, varied income households and age groups. The initial static website of 1999 with only Web Presence has now evolved into a portal with audio/video facility for disabled and multi lingual civic community. This council stays now at Transaction stage of eGovernment maturity i.e. above mid-level, heading towards politically participatory eDemocracy stage. Hence, it may be very well seen that fervor of 'State Social Responsibility' in eGovernment evolution and 'Centrality of Citizen' (balancing four dimensions of Citizen) are contributing to the successful and evolutionary maturity of eGovernment in this city council in Australia. This council, despite its small size in geography and population is poised to become a model for other councils to emulate.

Our study clearly shows that deeming eGovernment as SSR with Centrality of Citizen determines the successful maturity of any eGovernment initiative to evolve into wholly-politicallyparticipatory eDemocracy stage. The SSR, VOTERS EDG and Centrality of Citizen frameworks show how a human face could be given to globalization. Globalization protagonists emphasize on de-regulation reforming of local legislations, opening up the economies for foreign markets for allowing forces of market to play for businesses and citizens/customers. However, there has been no argument in favor of individuals/citizens to be enlightened on the governance, global marketing forces, the rightful place of citizens as stakeholders and customers and as guardians of democracies. Our research and analysis based on a grass-root local government that has considered governance and eGovernance as State Social Responsibility and forming a bridge with citizens through VOTERS EDG frame work to make individual citizens as informed and being at the center of globalization forces. As can be seen from the efforts of the City of Plenty, Social Media and ICTs per se are not the powerful ones, but organizing civil society and enabling them to plan to use social media and ICTS is the deciding factor for these media to prove useful socially and economically. In this paper, our research and analysis has thrown light on these aspects for ushering in a holistic globalization by elevating citizen as an informed individual.

Would it not be wise to use the power of Word of Mouse in a positive way by consciously training and involving citizenry in decision making and agenda setting activities of governments though eGovernance; rather than allowing the citizenry to take up cudgels though the same social media and ICTs?

\section{References}

American Society for Public Administration (2008): The Survey, Public Attitudes, Toward Government

Accountability and Transparency. Accessed www.google.com on 15 January, 2011

Australian Government Data Center Strategy: 2010-2025. (2010). Retrieved March 30, 2010 from www.egov.vic.gov.au/focus-on-countries/australia/trends-and-issues

Brady, R. \& Rubens, A. (2010). Contextualizing Information Ethics: Business Relations in Europe and in the 
US and the Accountabilities of Exchanging Information. In P. Parycek\& A. Prosser (Eds.), EDEM2010

Proceedings of the $4^{\text {th }}$ International Conference on E-Democracy, (pp 207-220), Osterreichishe Computer Gesellschaft, ISBN 978-3-85403-265-6.

Bruns, A., \& Wilson, J. (2009) Citizen Communication From Above and Below: The Australian Perspective. In A. Prosser and P.Parycek (eds) EDem 2009, Austrian Comp. Society. Vienna, 2009.

Caroll, A.B. (1989). Collaboration and Cintrol in Stakeholder Management: Business and Society, Cincinnatti: South Western

City of Plenty (1999). Electronic Services Delivery, an eGovernment Strategy Document, City of Plenty, Melbourne, Australia

City portal, (2011). Retrieved January 10, 2011 from www.google.com

Colesca S.E. \&Dobrica.L. (2008). Adoption and Use of E-Government Services: The Case of Romania. Journal of Applied Research and Technology, Vol.6, No.3 (pp 204-217).

Council Annual Report. (2011). Retrieved January 10, 2011 from www.google.com

Cunningham, G. M. \& Harris, J. E. (2001). A Heuristic Framework for Accountability of Governmental Subunits. Public Management Review.Vol. 3, No.2, (pp 145-165).

Das, J., DiRienzo, C. \&Burbridge J. Jr.(2008). Global E-Government and the Role of Trust: A Cross Country Analysis. International Journal of Electronic Government Reseach, Vol.5, Iss. 1 (pp 1-18).

DeBono, E. (1999). Multimedia Strategy, City of Quiet Sea, Policy Document, Melbourne, Australia

Elliman, T., Irani, Z. \& Jackson, P. (2007). Establishing a Framework for eGovernment Research: Project VIEGO. Transforming Government: People, Process and Policy. Vol.1, Iss.4, (pp 364376).

Freeman, R.E. (1984). Strategic Management: A Stakeholder Approach. Bostonb: Harper Collins. Groznik, A., Kovacic, A. \&Trkman, P. (2008). The Role of Business Renovation and Information in E-Government. The Journal of Computer Information Systems, Vol. 49, No. 1, (pp 80-88).

Hacker, K. L., Mason, S. M. \& Morgan, E. L. ( 2009). Digital Disempowerment in a Network Society. International Journal of Electronic Government Research.Vol.5, Iss. 2, ( pp 57-71).

Karna, S. R. (2010). The Process of Process Innovation for City EGovernance: Australian Authority Case. EGOV 2010 - IFIP e-government conference 2010 from 30.08.2010 to 03.09.2010 at Lausanne, Switzerland.http://www.slideshare.net/raokarna/slides-lausanna-e-gov

Karna, S.R and Sumita, U. (2010a). Business Process Innovation for G 2 C City eGovernance: Australian City Council eGovernment Case. Conference on Electronic Democracy. In A' Prosser and P.Parycek (eds) EDem 2010, Austrian Computer Society, Vienna, 2009.

Karna, S.R (2012). The Largest Democracy (India) Poised for Electronic Government and Electronic Democrtacy.Suggested Framework: Verifiable, Open, Transparent, Empathetic, Responsive and Senstive (VOTERS) eDemocracy.Conference on Electronic Democracy. In P.Parycek and N Edelman(eds) EDem 2012 Austrian Computer Society, Vienna, 2012.

Lim, E. T. K, Tan, C. W. \& Pan, S. L. (2007). E-Government Implementation: Balancing Collaboration and Control in Stakeholder Management, International Journal of Electronic Government Research. Vol.3, Iss.2 (pp 1-28).

Linhart, J.\& Papp, L. (2010). Bridging the Gap between Bottom-up and Top-Down eParticipation Approaches: eParticipation as Active Citizenship. In P. Parycek\& A. Prosser (Eds.), EDEM2010 Proceedings of the $4^{\text {th }}$ International Conference on E-Democracy, (pp 153-161), Osterreichishe Computer Gesellschaft, ISBN 978-3-85403-265-6.

Mbera, E. (2012). Towards budget transparency and improvement in the South Kivu Province. In Peter Parycek and Noella Edelmann (Eds.), CeDem 2012 Proceedings of International 
Conference on E-Democracy and Open Government 2012, (pp 47-58), Austrian Federal Computing Centre and Austrian Institute of Technology, ISBN: 978-3-90250525-5.

Mcloughlin, I. \&Cornford J. (2006). Transformational Change in the Local State?Enacting egovernment in English local Authorities.Journal of Management \& Organization. Vol.12, Iss.3 (pp 195-208).

National Broadband Network, Australia: Downloaded on 29-11-2012: http://www.nbnco.com.au/rollout/

NBN Co (2012). http://www.nbnco.com.au/rollout/about-the-nbn.html?icid=pub:rollout:1yr:bod:abtnbn-Ip, downloaded on 29-11-2012

O'Toole, K. (2007). E-Governance in Australian Local Government: Spinning a Web Around Community?. International Journal of Electronic Government Research, vol3, Iss. 4 (pp 58-83).

Paskaleva, K. (2008). Assessing Local Readiness for City E-Governance in Europe, International Journal of Electronic Government Research.Oct-Dec, Vol.4, Iss.4, pp.17-36.

Seifert,J.W. \& Chung, J. (2009). Using E-Government to Reinforce Government - Citizen Relationships - Comparing Government Reform in the United States and China.Social Science Computer Review, Vol.27, No.1 (pp 3-23).

Sharma S. (2007). New Mantras in Corporate Corridors - From Ancient Roots to Global Routes. New Age Publishers: New Delhi. p 44

Sharma, S.(2010). Beyond Pyramid and Pyramid Thinking: Pyramid vs. Coconut model of Thinking. Paper presented at 13th Annual Conference of the Strategic Management Forum (SMF) held at IIM Lucknow Greater Noida Campus. Retrieved January 10, 2011 from http://www.shunyacreations.com/Coconut Model of Society.pdf

Schuller, (2011)., In P. Parycek\&Kripps (Eds.), eDEM2011 Proceedings of the 5th International Conference on E-Democracy, (pp 235-248), Osterreichishe Computer Gesellschaft, ISBN ISBN: 978-3-90250520-1

CeDEM, 2011

Staff (2009). Economist e-Readiness Rankings Show Uneven Progress: E- Government Development, I Ways Journal of Government Policy and Regulations. Vol.32, Iss.1 (pp 15-17).

Svensson, J. (2010), The Expressive Turn of Political participation and Citizenship in the Digital Age. In P. Parycek\& A. Prosser (Eds.), EDEM2010 Proceedings of the 4th International Conference on E-Democracy, (pp 67-77), Osterreichishe Computer Gesellschaft, ISBN 978-385403-265-6.

Siau, K. and Long, Y. (2005).Synthesizing e-government stage models-a meta-synthesis based on meta-ethnography approach. Indus. Manage. Data Syst., 105 ( pp 443-458).

UNGlobal E-Government Readiness Report (2005). From E-Government to E-Inclusion. Retrieved January 15, 2011 from http://unpan1.un.org/intradoc/groups/public/documents/un/unpan021888.pdf

UN E-Government Survey (2008).From e-Government to Connected Governance. Retrieved January 15, 2011 from http://unpan1.un.org/intradoc/groups/public/documents/un/unpan028607.pdf

UN E-Government Survey (2010).Leveraging E-Government at a Time of Financial and Economic Crisis. Retrieved January 15, 2011 from http://unpan1.un.org/intradoc/groups/public/documents/UN-DPADM/UNPAN038853.pdf

UN E-Government Survey (2012). E-Government for the People. Retrieved November 29, 2012 from https://www.google.co.in/search?q=United+Nations+Global+EGovernment+Survey+2012\&ie=utf-8\&oe=utf-8\&aq=t\&rls=org.mozilla:enUS:official\&client=firefox-a

Williamson, A. (2010). Distribution and Empowerment: Embedding Citizens at the Heart of Democracy. In P. Parycek\& A. Prosser (Eds.), EDEM2010 Proceedings of the $4^{\text {th }}$ International 
Conference on E-Democracy, (pp 53-63), Osterreichishe Computer Gesellschaft, ISBN 978-385403-265-6.

Wong, W. \& Welch, E. (2004). Does E-Government Promote Accountability? A Comparative Analysis of Website Openness and Government Accountability.Governance: An international Journal of Policy, Administration, and Institutions, Vol.17, No.2, (pp 275-297)

Wong, K., Fearon, C., \& Philip, G. (2007). Understanding eGovernment and eGovernance: Stakeholders, Partnerships and CSR, International Journal of Quality and Reliability Management, Vol.24, No.9 (pp 927-943)

Yin, R. (2003). Case study Research: Design and Methods, $3^{\text {rd }}$ Edition. SAGE Publications: Thousand Oaks, London, New Delhi.

\begin{abstract}
About the Authors
Mr.Singara Rao Karna, is a visiting faculty in Marketing, International Business and Strategic Management. Mr.Karna has been involved with eGovernemnt research for over a decade, since year 2000 through his assignments in Australian and New Zealand city councils. Currently, Norway, Austria, Japan and S.Korea are being studied for eGovernment maturity levels. Other research interests include Electronic Marketing Strategies, Business Process Innovation and eCRM.
\end{abstract}

Dr. Divya Kirti Gupta is working as Associate Professor, Indus Business Academy (IBA), Greater Noida, UP, INDIA. She is co-drafter of ISO26000, International Standard on Social Responsibility of organizations and is Expert Member of ISO26000 Post Publication Organization Stakeholder Advisory Group (PPO SAG). The research interests include Corporate Social Responsibility, Organization Development and Management Thought. 